with a pure culture of Saccharomyces apiculatus, and then for the remaining days of their life with sterilised grape-must. Comparing the approximate number of cells of $S$. apiculatus originally given in the food with the great numbers of the same cells gathered successively in the excreta during several days, it was evident that the yeast cells had greatly multiplied. It was calculated that in the droplet of must containing the S. apiculatus, with which each fly was first fed, the number of yeast cells must have been about 500,000; now, continuing to feed these flies with sterilised must, the number of yeast cells expelled each time from the intestine was reckoned to be from 400,000 to 600,000 , and perhaps more. In one of these pinioned flies, that lived for eight days, the yeast cells calculated for one excretal drop on the seventh day of confinement were more than $2,500,000$; this fly, which had been fed originally with about 500,000 yeast cells, must have emitted, during the eight days in which no yeast was given to it, about $35,000,000$ cells. In some cases, especially when excretion was not frequent, the excrementitious droplet was one mass of $S$. apiculatus. There can be no doubt, therefore, that the yeast cells increase in numbers while inside the body of the insect. This was further proved by pinioning, in the manner described, some blue meat-flies just caught, feeding them exclusively with sterilised must, and examining all the excreta during the remaining days of their life ;

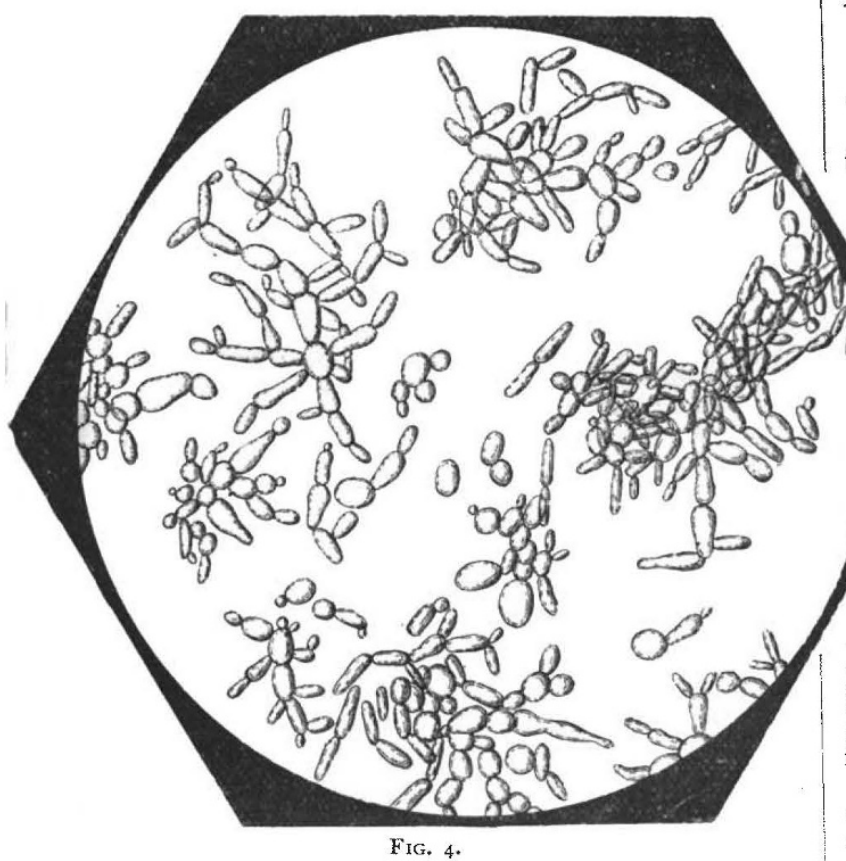

it was found that $S$. apiculatus cells, not very abundant at first, increased greatly during the succeeding days ; in these cases all the yeast cells excreted were derived from the Sacharomyces contained in the insect before captivity, gathered with its fond whilst in the free state.

On pinioning blue meat-flies in a Petri-box, and feeding them exclusively with sterilised must, $S$. apiculatus appears com. monly in the excreta, but rarely is $S$. ellipsoideus observed. This may be due both to the scarcity of $S$. ellipsoideus in the usual food of the meat-flies, and to the struggle between the various yeasts and other organisms that develop in the digestive tube. On feeding a blue meat-fly only once with a mixture of $S$. apiculatus and $S$. mycoderma, and then feeding it with sterilised must exclusively, it was observed that at first the excreta contained both the yeasts in about equal proportions; but gradually apiculatus had the upper hand on con. tinuing to feed with must; but if the insect was made to fast, the quantity of $S$. apiculatus in the excreta diminished rapidly, and those of the mycoderma greatly increased. This shows how greatly the conditions inside the intestine of the insect must influence the development of the different yeast germs.

Some observations by Drs. Amedeo and Antonio Berlese, on the internal anatomy of flies (Drosophila cellaris and common

No. I 459 . Vol. 56$]$ flies), contribute much to explain how it is that the yeasts can accumulate in great numbers and multiply inside the organism of these insects. It is known that the juices sucked up by means of the proboscis do not go directly into the intestine, but are stored up in the crop, or ingluvies, a special organ which, through a long tube, communicates with the œsophagus, at the upper part of the digestive tract. On examining the crop of many flies, it was found replete with a syrupy liquid, a concentrated sugar solution, capable of rapidly reducing Fehling's solution, in which yeast cells are observable, besides Dematium, Torula, Bacteria and ciliated infusoria. It is probable that in the sugary solution contained in the ingluvies (unless the solution be too concentrated to permit the process) the multiplication of the yeast cells must chiefly occur.

The experiments of Dr. Amedeo Berlese thus prove conclusively the great part that insects, especially ants and several kinds of flies, take, not only in the distribution (as was hitherto known), but also in the preservation and multiplication of alcoholic ferments. Insects, far more than atmospheric air, contribute to the dissemination of yeasts, wnich they convey rather internally than externally. There is, moreover, reason for believing that during the cold season some yeasts are chiefly preserved and, perhaps, increased within the organism of insects.

ITALO GIGLIOLI.

\section{TEN YEARS' WORK OF THE ROYAL} GARDENS, KEW:

THE completion of the tenth annual volume of the Kere Bu?letin has made it desirable to publish a detailed index to the whole series. As the number of volumes has increased it has become more difficult to find the information they may contain on any particular subject.

The opportunity may be taken to pass in review briefly the more important subjects which have been treated. This will have the more interest as the period covered has been one of more than usual activity in the development of our tropical possessions.

Kew, from its first establishment as a national institution in I84I, has always been applied to by men of business desirous of engaging in new industries. Response to individual inquiries gradually came to be regarded as insufficient, and a demand arose for the prompt publication for general use of any information likely to be of service to those engaged in colonial pursuits. With this object the first number of the Bulletin was issued in January 1887. But it was also intended to serve another purpose. When public attention is engaged by any particular subject, inquiries about it are numerous. To say all there is to be said about it, once for all, in the pages of the Bulletin effects a great saving in labour. To quote the prefatory notice to the first number :-

"It is hoped that while these notes will serve the purpose of an expeditious mode of communication to the numerous correspondents of Kew in distant parts of the Empire, they may also be of service to members of the general public interested in planting or agricultural business in India and the Colonies:"

On March 18, 1887, the First Commissioner of Her Majesty's Works and Public Buildings (Mr. Plunket) informed the House of Commons:-.." In response to the demands for the publication more speedily than in the annual report of information received from abroad, I have sanctioned the publication of a monthly bulletin, which can be purchased for a small sum."

Publication was originally intended to be "occasional." It has not been found practically possible to keep up an absolutely regular monthly issue. This, however, has been approached as nearly as circumstances would allow.

The original intention was to confine the Bulletin to colonial and commercial information. The suggestion of a larger scope having been raised in Parliament, especially with regard to reports on expeditions, the materials collected by which had been entrusted to Kew, to notices of interesting plants or objects received and the important plants sent out, Mr. Plunket further decided that the "Bulletin. . . should be made the vehicle of all printed matter suitable for its pages, which it is desirable to issue from Kew." As a sequel the Bulletin became, what it remains, a continuous record of Kew work in all its various aspects.

1 Reprinted from the Kerv Bulletin of Miscellaneous Information, N... ז20. 


\section{Botanic Stations.}

The establishment and development of the institutions known as Botanic Stations belongs alınost entirely to the period under review. These stations were first suggested in 1885 to meet the special requirements of the smaller islands in the West Indies $(K . B$., I887, June I-I2), where "a great want was felt for reliable information on the culture of new economic plants and plain practical hints as to the best means to be employed for rendering them of the greatest value" $(p .7)$. This information was intended to be supplied by a regular system of bulletins supplemented by the maintenance of stations with nurseries attached for supplying seeds and plants. The officers in charge of the stations were men selected mostly from Kew, with a sound knowledge of gardening and capable of showing experimentally the conditions under which tropical economic plants might best be utilised as objects of remunerative industry

The scheme met with the approval of the late Earl of Derby, and has been supported by successive Secretaries of State.

The details of its working have devolved largely on Kew, which has been continuously drawn upon for men, plants, advice, and information.

The first Botanic Stations were started at Grenada and Barbados, in 1886 . These were soon followed by similar stations at St. Lucia ( 1889 ), Dominica and other islands in the Leeward Group (I889), St. Vincent (I890), and afterwards at British Honduras (1894). There are now nine stations in all in the West Indies.

The Grenada station was established on a spot just outside the town of St. George, described by the Governor as a "good site, well watered, accessible, and apparently suitable in every way." The first grant was $300 l$., with a further sum of $1000 l$. towards establishing and laying out the garden and providing a house for the curator. The objects of this garden were stated as follows: "To introduce and distribute plants of great economic value, to supply practical hints respecting new and promising industries, and to develop and improve existing minor industries " (K.B., I887, June I2). An account of the interesting station at St. Vincent, established on the site of the old botanic garden that existed from 1765 to 1823 , was given with a drawing of the curator's house $(K . B ., 1892,92)$. Several references are made to the excellent work done in the Botanic Garden at Dominica, which promises to be one of the most attractive and useful in the West Indies (K.B., I893, 148).

Following the example of the West Indies, there have been established five Botanic Stations on the West Coast of Africa. The earliest was started at Lagos by Sir Alfred Moloney in I888; the next at Aburi on the Gold Coast, in which Sir W. Brandford Griffiths took a deep personal interest, in 1890. Since then stations have been established both at the Gambia (1894), in the Niger Coast Protectorate (I89I), and at Sierra Leone ( 1895$)$. A further station has been established in Fij by the efforts of Sir John Thurston (1889). The results attained by these Botanic Stations have been so promising that a strong wish has been expressed by the local authorities to obtain similar institutions at Bermuda, Bahamas, and the Seychelles.

\section{Fruit Trade.}

One of the most interesting developments in Colonial enterprise in recent years has been the increasing trade in fruit. Jamaica led the way, largely owing to the encouragement of the late Sir Anthony Musgrave, by supplying the United States with bananas and oranges that hitherto had had no local commercial value. The Jamaica fruit trade is now of the annual value of more than half a million sterling, and employs a considerable number of vessels wholly engaged in it. The trade in fruit between the Southern Colonies of the Old World (the Cape and Australia) and the mother country, is another instance of commercial activity in a new direction. It is not yet ten years old, but the value of the fruit annually imported is very considerable. The first steps in this direction were undertaken on the suggestion of Kew, and led to the excellent display of fruit made at the Colonial and Indian Exhibition in I886. This showed so strikingly the capabilities of the Australian Colonies and the Cape to ship fresh fruit to this country during the winter months, that considerable effort was made to establish what is now regarded as an important trade.

In the Bulletin for the years 1887 and 1888 will be found a summary of information not accessible in any other form in regard to the capabilities of various parts of the Empire for the production of fruit. This was brought together through the aid of reports oltained by the Secretary of State for the Colonies, and is still the most authoritative source of information on the subject. The efforts now being made to ship various tropical fruits from the West Indies direct to this country is another direction in which great results may ultimately be attained. The popular taste for the consumption of bananas is increasing. It has been shown that many such fruits can be brought to the home country in a fresh condition and find a ready market.

Information is also given respecting certain kinds that have been introduced with the aid of Kew from the West to the East Indies (K.B., August I, I887). Among these the Tree Tomato, the Chocho, and the Cherimoyer have proved useful additions to the food supply of hill stations in India and Ceylon. On the other hand new varieties of bananas and mangoes, the Durian and the Mangosteen, have been transferred from the East to the West Indies.

\section{Decades Kewenses.}

Under the title of "Decades Kewenses" descriptions of plants new to science have reached the thirtieth decade. These are based on specimens contributed from every region on the earth's surface from the extreme heights of Tibet to the shores of the remotest islet in the Pacific Ocean. Further, owing to the increased impulse to exploration and commercial enterprise in Tropical Africa, it was thought desirable to publish at once, but in a separate series, brief diagnoses of new species. This has been done in the "Diagnoses Africanæ" (I894 to I895).

\section{Floras.}

Besides these the vegetation of special regions investigated at Kew as the result of collections communicated by expeditions and travellers, appear under numerous headings as the Flora of the Solomon Islands (K.B., I894, 2 I I ; I895, I32, I 59); of Aldabra Islands (K.B., I894, 146); of Formosa (K.B., I896, $65)$; of St. Vincent and adjacent islets $(K . B .1893,231)$; of the Gambia Delimitation Commission (K.B., I891, 268; I892, $45)$; of the Sikkim-Tibet frontier (1893, 297); of Tibet (K.B., I894, I36); of the Hadramaut Expedition (K.B., I894, 328 ; I 895,315$)$; Siam plants $(K . B ., 1895,38)$. Amongst investigations of the economic products of various regions are articles on the Agricultural industries of the Gambia $(K . B ., 1889,242)$, Economic plants of Madagascar (K.B., I890, 200); Agricultural resources of Zanzibar $(K . B ., 1892,87)$; Economic plants of Sierra Leone (K.B., I893, I67); and Plant industries of Lagos (K.B., I893, I80).

\section{ORCHIDS.}

The cultivation of orchids is one of the most prominent features of English horticulture. Every part of the world is ransacked for them by collectors. Of no family of plants have more species been got together in a living state, and in no country are a greater number maintained under cultural conditions than in England. During his lifetime, the late Dr. Reichenbach, Professor of Botany at Hamburg, was the acknowledged authority for their nomenclature. On his death in I 889 vigorous public pressure was brought to bear on Kew to take up his work. This was done, though not without difficulty, in addition to its other duties, and in 1891 the publication of technical descriptions of new species was commenced. Twenty decades of "new orchids" have been published in the Bulletin.

\section{HORTICULTURE.}

Of horticultural interest a list enumerating 766 species and varieties of orchids that flowered at Kew during the year I 890 has been published $(K . B ., 1891,52)$, affording useful informa. tion as to the time and duration of the flowering period of orchids cultivated in this country. The highest number of species flowered in one month was 125 in May; the lowest was 85 in January. Some species, as for instance Cypripedium longifolium, Masdevallia pulvinaris, and Odontoglossum crispum, were in flower all through the year.

The cultivation of tropical and sub-tropical plants on the Riviera was described $(K . B ., 1889,287)$, with notes on the principal palms, cycads, bamboos, agaves, and other succulent plants. To this was added a list of some of the most interesting other species established on the Riviera, revising in many cases the names under which they had hitherto been recognised. A further contribution was made to this subject by a paper written by Mr. J. G. Baker, F.R.S., on the agaves and arborescent ilacere on the Riviera (K.B., I892, I). As few botanists have attended much to these plants, it has been very difficult for

NO. [459, VOL 56] 
cultivators to obtain names for their collections. A correct determination of cultivated Riviera plants is also of value to Kew, as it assists in the interchange or purchase of new and desirable specimens required for the establishment.

An important paper on horticulture and arboriculture in the United States, prepared by the curator, Mr. G. Nicholson, whilst on a visit, as a judge in horticulture at the Columbian Exposition at Chicago $(K . B ., 1894,37)$, has rendered it possible to obtain a more complete representation of the trees and shrubs of the United States in the Arboretum of the Royal Gardens, and has brought before horticulturists in this country many interesting plants that had not hitherto received the attention they deserved. Nearer home, a paper on Horticulture in Cornwall $(K . B .1893,355)$ affords a fairly representative picture of the possibilities of Cornish horticulture, where, owing to the mildness of the climate, types of the vegetation of New Zealand and the Himalaya do better even than under glass at Kew. The "cultivation of vegetables for market" and the possibilities of market gardening in Great Britain (K.B., I895, 307) discusses an important economic problem.

Among other horticultural subjects dealt with are the storing of home-grown fruit $(K . B ., 1895,3 \mathrm{I}$, with an illustration of a fruit room), and a detailed account of the prune industry in France and California.

\section{Plant Diseases.}

The diseases of cultivated plants is a subject on which the aid of Kew is frequently sought on behalf of Colonial Governments by the Secretary of State for the Colonies. The investigation of fungoid diseases often demands considerable time and attention on the part of members of the Kew staff, while those caused by insects render it necessary to secure the assistance of specially qualified experts to whose courtesy this establishment is greatly indebted. The several diseases that have affected the sugarcane in the West Indies, Queensland, and Mauritius have been described in a series of important articles extending over several years (1890-96), whilst diseases such as those affecting arrowroot in St. Vincent, bananas in Fiji, cocoa-nut in British Honduras, coffee in East Africa, onions in Bermuda, wheat in Cyprus, pepper in Mysore, potatoes in India, vanilla in the Seychelles, have also been carefully dealt with. Of considerable practical value are articles on the preservation of grain from weevils (K.B., 1890, 144), and on the well-known plant malady called " anbury" and " finger and toe," which attacks turnips (K.B., 1895, I29). It is shown that free acid present in the soil is favourable to the disease, while a free alkali is unfavourable.

\section{Fibre Plants.}

The large and increasing interest taken in fibre plants, and the numerous references made to this establishment on the subject, rendered it desirable to place within reach of cultivators in India and the Colonies a summary of information respecting them. This is contained in a series of articles begun in 1887 , and continued with more or less regularity to the present time. The total number amounts to about seventy. As might be expected, those of chief importance relate to Sisal hemp and Ramie, or China grass, subjects which have received much attention in various parts of the Empire. These articles are of value, not only in encouraging the cultivation of plants yielding fibres likely to be in actual demand, and yielding remunerative results, but in preventing expenditure upon those that are known to be useless.

Many fibres have been traced to the plants yielding them for the first time. For instance, the Mexican whisk, or Raiz de Zacaton, was identified, from specimens communicated by the Foreign Office, at the root of a species of Epicampes, a grass distributed over the highlands of Mexico. The plants yielding the fibre called Istle, used, not for rope making, but as a substitute for animal bristles in the manufacture of cheap nail and scrubbing brushes, were found to belong to a group of Agares with short leaves, of which Agave heteracantha, Zucc, , is the type. The first information respecting African bass, a fibre obtained from Raphia vinifera, was published in the Kerw Bulletin (K.B., 1891, p. I). This is now a regular article of export from our African Colonies; and the same thing may be said of the bass fibre obtained from the Palmyra palm in Ceylon (K.B., 1892, 148), and of Madagascar Piasava yielded by a new species of Dictyosperma $(K . B$., I 894,358$)$. A continuous account of the hemp industry in Yucatan, an $I$ of the similar industry lately started in the Bahamas, is given over the whole NO. I 459, VOL. 56] period. The origin of the white-rope fibres which appeared in commerce as Bombay aloe fibre, and as Manila aloe fibre, have been traced to Agave vivipara, a New World species now naturalised and fairly abundant in many parts of the East Indies (K.B., 1893,78$)$.

The recent attempts to extract and to utilise the valuable fibres contained in the China grass (Boehmeria nivea), and Ramie or Rhea $(B$. tenacissima), have been placed on record in a series of articles which have been of considerable service to manufacturers in this country and also to our planting Colonies. The habits and requirements of the plants and the conditions necessary for their successful cultivation have been carefully discussed.

\section{Rubber Plants.}

The investigation of rubber-yielding plants has resulted in drawing attention not only to new sources of supply, but in increasing the quantity available for commercial purposes. The remarkable rubber industry started in the Colony of Lagos in $\mathrm{I} 889$ is described (K.B., I 895, p. $24 \mathrm{I}$ ), and a figure is given of the plant, which hitherto had not been known as a source of commercial rubber. The Lagos rubber industry in two years developed into an export value of nearly 400,000 . A somewhat similar industry has been started on the Gold Coast by the efforts of Sir Alfred Moloney, with exports in 1893 of the value of $218,162 l$. Practically all the more important sources of commercial rubber are reviewed, while particulars respecting two rubber plants, such as Forsteronia gracilis in British Guiana, F. foribunda in Jamaica, and Safium slandulosum in the United States of Columbia, are also given. It may be added that information is desired by this establishment respecting the plants yielding the Esmeralda rubber of Guiana $(K . B ., 1892,70)$ and that exported from Matto-grosso in Brazil. There is a doubt as to the distinction, if any, existing between caoutchoucs yielded respectively by the Ule and Tuno trees of Central America. One of these is usually referred to Castilloa elastica, but botanical specimens are necessary of each tree to definitely decide the point.

\section{Special Articles.}

These include the results of investigations made at Kew into plants yielding Paraguay tea, or maté, so largely consumed as a beverage in South America $(K . B ., 1872,132)$; vanilla-yielding plants cultivated in tropical countries $(K . B ., 1895,169)$; the plants yielding Sisal hemp, (K.B., I892, 21); the timber of the Straits Settlements $(K . B .$, I 890, I I 2$)$; the species and varieties of Musa cultivated for food or ornament $(K . B ., 1894,229)$; tropical fodder grasses (K.B., I894, 373: 1896, I 15); Chinese white wax $(K . B ., 1893,84)$; the arrowrnot industry of St. Vincent $(K . B ., 1893,191)$; tuberous Labiatæ $(K . B ., 1894,10)$; Canary rosewoods (K.B., I893, I33) ; American ginseng (K.B., $1893,71)$; palm weevil in British Honduras $(K . B ., 1893,27)$; and sheep bushes and salt bushes (K.B., 1896, I29). In addition several articles have appeared describing the various forms in which tea is met with in European and Asiatic commerce. P"u-êrh tea is made into balls as big as a man's head, or into cakes; compressed or tablet tea is manufactured from tea dust by steam machinery; while another form known as brick tea is used in Chinese Mongolia and Tibet. Lao tea is not used for making an infusion, but prepared wholly for chewing purposes. A pickled tea, called Leppett tea, is eaten as a preserve with other articles. The white tea of Persia has been shown to consist of the undeveloped leaf-buds of China tea thickly coated with fine hairs giving them a silvery appearance. A singular beverage known as Faham tea is prepared in Mauritius from the leaves of an orchid (Angracum fragrans) (K.B., 1892, I81). This is described as agreeable and used as a digestive; it is even recommended in diseases of the respiratory organs. The leaves themselves mixed with ordinary tea impart to the latter an extremely pleasant perfume.

The discovery of seedling sugar-canes at Barbados $\left(K^{\prime} B\right.$., 1889,242 ) has rendered it practicable to raise new serviceable varieties, and probably to improve the yield of this valuable plant. A seedling raised at Kew has yielded excellent ' results in Queensland, and has been largely propagated under the name of "Kewensis" (K.B., I896, I67). The possibility of preparing a palatable butter from the oil of the cocoa-nut ( $K . B$., $1890,230)$ is an instance of the advance made in the chemistry of familiar vegetable products. Canaigre $(K . B ., 1890,63)$ will probably prove a most valuable tanning agent, while the preparation of cutch from the bark of mangrove trees (K.B., I892, 
227) may bring into profitable use stretches of vegetation in the tropics that have hitherto been regarded as perfectly useless. Amongst new economic plants should be mentioned Coffea stenophylla, the highland coffee of Sierra Leone $(K . B ., 1896$, 189 ), which in certain localities may prove a formidable rival of the Arabian coffee.

The publication of a note on Jarrah timber $(K . B ., 1890$, I 88 ) has led to the extended use of this and similar Australian hard woods for the purpose of paving the carriage-ways of London streets instead of the cheaper but less durable white pine. The collections of Australian timbers in Museum III. were of special service in this direction.

A paper on Natural Sugar in Tubacco (K.B., I896, 49-55) recorded some scientific facts of great novelty and interest, and solved an important fiscal problem.

\section{DRUGS.}

Many little-known drugs have been investigated. The seeds of Sophora secundiflora have a singular use among the Indians of Mexico, where they are taken as an intoxicant. Half a seed is said to produce exhilaration followed by sleep lasting two or three days $(K . B ., 1892,216)$

Derriselliptica, now growing in the Economic House at Kew, yields the Malayan fish poison known as "Aker Tuba" (K.B., I892, 216). From the account given of Natal Aloes and of the plants supposed to yield this product $(K . B ., 1890,163)$ it appears that it differs in some important respects from the more commonly known Cape Aloes. The discovery of the plant, also in the Kew collection, yielding the true Star Anise of commerce is noticed $(K . B ., 1888, \mathrm{r} .73)$. The manufacture of quinine in India, and the wide distribution at a nominal price of this valuable medicinal agent amongst the natives $(K . B ., 1890,29)$, is one of the most important services which European rule has rendered to the Indian Empire. Paraguay Jaborandi (Pilocarpus) is discussed $(K . B ., 1891,179)$ from materials sent to this country by H.M.'s chargé d'affaires at Buenos Ayres in $188 \mathrm{r}$. The origin of myrrh and frankincense is discussed in considerable detail $(K . B, \mathrm{x} 896,86)$, while the first authentic information respecting the district whence Siam Benzoin or Gum Benjamin of commerce is obtained is the subject of another article (K.B., 1895, 154). Next to Gum Benjamin, Siam Gamboge is the most interesting of Siamese products $(K . B ., \mathrm{I} 895, \mathrm{I} 39)$. The peculiar Ai Camphor prepared in China from a shrubby composite, a species of Blumea, is described (with a plate) from information supplied by Dr. Augustine Henry $(K . B ., 1895,275)$. The plants yielding the leaves known as coca, and the drug cocaine, with their characteristics, are discussed $(K . B ., 1889,1)$, with a suggestion that a plant long cultivated at Kew (Erythroxylon Coca, var. nozlo granatense) might be suited for cultivation at a lower elevation than the type. The little-known Iboga root of the Gaboon and Bocca of the Congo, possessing tonic properties, is traced to Tabernanthe 1boga, Baill. (K.B., I895, 37 ) ; the tree yielding the Ipoh poison of the Malay peninsula is identified with that yielding the Upas poison of Java $(K . B$., $1891,24)$; but the remarkable point is brought out that while in Java the Upas tree (Antiaris toxicaria) furnishes a very effective arrow poison, in the. Malay peninsula the juice of what is regarded as an identical species is apparently innocuous, and the defect is remedied by the use of arsenic.

\section{FOOD GRAINS.}

A series of articles on the food grains of India by Prof. A. H. Church, F.R.S. (1888 to 1893 ), supplements the information contained in his published handbook on the same subject. The materials for these investigations were supplied from the Museums of the Royal Gardens.

\section{Miscellaneous Notes.}

In I $89 \mathrm{I}$ a series of miscellaneous notes was begun, in which were recorded appointments on the Kew staff as well as those made on the recommendation of Kew by the respective Secretaries of State to Colonial and Indian Botanical Gardens. The notes also included a record of contributions made to the gardens, herbarium, and museums, the movements of expeditions and travellers engaged in botanical exploration, notices of Kew publications, and facts of interest connected with the daily work of the establishment. Later there were added paragraphs on general economic subjects too short to appear as separate articles. The detailed index now published will afford the means of reference to these scattered notices.

NO. I 459 , VOL. 56$]$

\section{A PPENDICES.}

The Appendices remain to be noticed. Of these three have been regularly issued at the end of each volume since 1891 . Previously the information contained in them had appeared as one of the monthly numbers of the Bulletin. (I) Lists of seeds of hardy herbaceous and of trees and shrubs offered in exchange by Kew to Colonial, Indian, and foreign botanical gardens ; (2) Lists of new garden plants annually described in botanical and horticultural publications. These are indispensable to the maintenance of a correct nomenclature in the smaller botanical establishments in correspondence with Kew, and afford information respecting new plants distributed from this establishment in regular course of exchange with other botanic gardens; (3) Lists of the staffs of the Royal Gardens, Kew, and of botanical establishments at home and in India and the Colonies in correspondence with Kew.

In Appendix III., 1890, will be found a complete index to the Reports on the Progress and Condition of the Royal Gardens, Kew, from 1862 to 1882 . This index is useful as a means of easy reference to the numerous notices respecting economic and other plants.

\section{CORRECTIONS.}

In so varied a range of subjects some amount of error, it is hoped not considerable, doubtless exists. A few statements which subsequent research have shown to be probably erroneous must be corrected.

The case of poisoning from Turnsole (Chrozophora tinctoria) described in $K . B ., 1889,279-280$, was in all probability not due to that plant, but to Datura Stramonium.

The source of the well-known Chinese preserved ginger, which in K.B., 1891,5 , was attributed to Alpinia Galanga, ultinately appeared to be, as pointed out in $K . B ., 1892$, 16 , the ordinary commercial plant, Zingiber officinale. Some mistake had been made apparently in the plants transmitted to Kew as yielding the commerical product.

The figure of a Musa given in K.B., 1894, 247, as Musa Fehi may be identical with that species. But all that is certain about it is that it represents M. Seemanni of Baron von Mueller.

\section{THE DUKE OF DEVONSHIRE ON SCIENTIFIC EDUCATION.}

$\mathrm{IN}$ opening a new technical college at Darlington on Friday last, the Duke of Devonshire made some valuable remarks upon the advantages of scientific instruction, and the need for the organisation of secondary education. Subjoined are a few extracts from the Times report of the address.

\section{Science and Art essentral to Commercial. PROSPERITY.}

The case for technical education, and for the improvement of technical education, the case for the adequate provision of the scientific and artistic education of our people, is within our judgment essential to the continued efficiency of our manufacturing and commercial interests, without the prosperity of which the people could not continue either to prosper or even to exist. Science and art now enter so largely into the practical conduct and management of every one of our industries that a knowledge of the principles of science and of art is as indispensable to their successful conduct as the possession of bodily strength is necessary for the working of the raw materials. Take the case of the intlustries in which you yourselves are specially interestedthe mining, the iron, and the steel industries. Science enters into every operation by which you extract coal or iron from the earth ; science enters into every process by which you convert coal into coke, into every operation in which iron ore, with the aid of coke, is converted into iron. Again, into every process in which the iron is converted into steel, and into every one of those processes by which steel is converted into the thousand articles in which it serves the purposes of the community, it is science and science only which has created, and which continues to improve, those vast and powerful machines by means of which the heat which is generated from coal is converted into power, and applied to the service of man. In every one of these processes - to speak only of those with which you are most familiar in this district-improvement and development are constantly taking place; and if in any respect 